\title{
AN ANALYSIS OF THE STUDENTS' ERROR ON CHANGING ACTIVE VOICE TO PASSIVE VOICE
}

\author{
Mohammad Darohim \\ darohimmohammad@gmail.com \\ English Language Education Department, Faculty of Teacher Training and Education, Universitas Islam \\ Lamongan
}

\begin{abstract}
In passive voice, the subject receives the action of the verb. It is often used both in spoken and written form. For the learners, to change the active into passive voice of the target language is very confusing. The students usually make errors in building passive sentences as they ignore some aspects required in arranging best form of passive sentence. The students of El-Madani Islamic Boarding School Deket Lamongan were confused to change the verb in different tenses. The type of this research is descriptive quantitative. The research was chosen because this type of research defines what exist and may help to reveal new point and meaning. The survey and experiment, which were used in this research, was the phenomena of English errors passive sentences made by the students. The population of this research is all the students of El-Madani Modern Islamic Boarding School.The researcher used test and questionnaire to collect the data. The result of this study shows that (1) the kinds of errors commonly made by the students in changing active voice to passive voice are errors of omission, errors of addition, errors of miss-formation, and errors of miss-ordering (2) The students have difficulties in understanding passive voice especially in four tenses, simple present tense, simple past tense, present continuous tense and past continuous tense. (3) Factors which affect students' ability in passive voice are: classroom atmosphere, lack of experience in using English, teacher's explanation was not clear enough, the differences between passive voice in Bahasa and English.
\end{abstract}

Keywords: Students' errors, passive voice

\section{INTRODUCTION}

Learning English is not easy; therefore, Indonesian learners are often confused to comprehend English because there are some differences between the English and Indonesian language systems. Besides, the Indonesian learners of English are influenced by Indonesian structure. Therefore, the learners have to be aware of that. Constructing English sentence needs some important rules, called grammar. The students who want to master English well should understand better the English grammar. Learning a language is supported by learning the components of the language, such as vocabulary, structure, pronunciation, and spelling. Lado (1996:163) states that learning is a foreign language can be defined for test purpose not only as learning to understand and be understood, but more especially as learning to use the structural units and 
patterns of the foreign language in validity situation. From this definition, it can be said that learning a foreign language is not just enough to understand the language but it is necessary to measure to what extend the learners ability to master the grammar or structure correctly in any situation.

Learning English cannot be separated from the errors, it does not mean that the errors give negative effects for the learner. Error can be an indicator of the learner's stages in their target language development even the teaching learning process is better as errors exist because the teacher and the students will know the lack of mastery and make the appropriate remedial for teaching to students. The students must learn through trial and error and the students will not get an improvement if they think that errors are faults that should be avoided. The fear of making mistakes leads to hesitancy among the students to say and write anything in the foreign language. In addition, errors and mistakes are different. Dulay, Burt and
Krashen (1982:139) state that mistakes are commonly processed by the performance factors such as fatigue and inattention. On the other hand, errors are caused by the competent factors which are continuous and consistent. In other words, errors are resulting from lack of knowledge of the rule of English.

Actually, every foreign language teacher will find out the errors made by the students both in oral and written forms. The students can be said to have made errors when the production of their oral and written expressions differs from the native speaker or target languages' norms. Corder (1947:125) states that error analysis is the examination of those errors committed by students in both the spoken and written medium. James (1998:58) describes that as mother tongue influences, errors in language learning are sometimes natural and tend to occur frequently. Therefore, the teachers must try their best to avoid the errors made by the students without discouraging them. In addition, 
knowledge of the sources of the errors will help the teachers to learn the errors in order to enable the students to construct the students with appropriate language form as stated by Slinker (1992: 119) that the self -correction of errors is indeed necessary and the teacher can serve an important function here.

\section{Constructing English sentence} needs some important rules, called grammar. The students who want to master English well should understand better the English grammar. Murcia and Hilles (1987) states that grammar often taught isolated, unconnected sentences that give a fragmented, unrealistic picture of English and make it difficult for students to apply what they learned in actual situations. Grammar is a central point. It includes the tenses as a core of the skill, such as: simple present tense, simple past tense, simple future tense, present continuous tense, present prefect tense, past continuous tense etc. In this case, the researcher limited three tenses, those are simple present tense, simple past tense, and simple future tense.

One of aspects in grammar that student should study is passive voice. Passive Voice is one of grammars that should be learned and understood by the students. In passive voice, the subject receives the action of the verb. It is often used both in spoken and written form. Besides that, there are three types of verbs in English and each is used in different condition and situation or it is usually called tenses. For the learners, to change the active into passive voice of the target language is very confusing. They have to pay attention to the verb used in active, which is different from the verb used in passive voice. In addition, it is very common in scientific writing and other kinds of expression where the writers are mostly interested in events and processes in things that happen. 
Passive voice is one of the aspects that should be given more attention by the English teachers. In learning the passive voice, usually students get confused with the tenses. The students do not fully understand about the change of forms. Like infinitive change into present participle or the past participles of regular verbs and irregular verbs of passive voice form. It is important because passive exists in both spoken and written English. Based on the statement above, passive sentences are an important part of English grammar that have to be mastered by the learners actively or passively. The learners have to own so high capability of English grammar so that they are able to speak and write correctly and grammatically. In real life communication with native or nonnative speaker, making errors do not become a big problem. But for the learners who learn English in academic affairs, making English errors will be a very serious problem in constructing correct passive sentences, the students need to master grammar for instance: tenses, auxiliaries (modal auxiliaries and auxiliaries $^{\text {ee }}$ verb), past participle verbs, etc. The students usually make errors in building passive sentences as they ignore some aspects required in arranging best form of passive sentence.

This phenomenon also happened in El-madani Islamic Boarding School Deket Lamongan, the students were confused to change the verb in different tenses. In this case, the students who learn English as the target language faced this particular phenomenon. In this study, the researcher has observed that the students of El-Madani Islamic Modern Boarding School Dandangan Deket Lamongan still have problem in using English passive voice. Therefore, the researcher has known the students' problems on grammar especially in changing the active voice to the passive voice. Sometimes the students do not fully understand the passive voice in a sentence. It is quite possible for them to make error. To avoid the same errors 
teacher should correct those errors, whereas those errors will give feedback to teachers in teaching grammar, especially the students of El-Madani Islamic Modern Boarding School Dandangan Deket Lamongan who have some errors in using passive voice.

In the researcher's preobservation during teaching, it could be seen that the errors made by the students of El-Madani Islamic Modern Boarding School Dandangan Deket Lamongan were mostly in verbs. They should use past participle in passive voice, but they used infinitive. Instead, they used infinitive in passive voice, but they should use past participle. To make a good composition, the students must be able to master and apply the structure correctly. Especially about the grammar used. But, they could not do that. Of course, errors will arise and automatically their writing will cause misunderstandings to the readers. The readers cannot receive the messages or expressions of their idea well. Most of the students still found problems in using it, because of their limited mastery, especially the differences between regular and irregular verbs.

\section{RESEARCH METHOD}

The research design that used in this study is descriptive quantitative. The descriptive quantitative research was chosen because this type of research defines what exist and may help to reveal new point and meaning. The survey and experiment, which were used in this research, was about the phenomena of English errors passive sentences made by the students of El-Madani Islamic Modern Boarding School. The method of this study is descriptive analysis method. First, the writer observed the passive voice material in students' book in the classroom. Second, she explained about passive voices in the classroom and then conducted the students' tests two times. 
The last, the writer interpreted the data about what kinds of errors that mostly students made. The researcher analyzed each students' error in student's answer based on Ellis' steps, they are collecting of the sample of learner language, identifying the errors, describing the errors, and then explaining the errors.

The population of this research is all the students of El-Madani Modern Islamic Boarding School that consist of 39 students. The students are taken from 1 KMI up to $6 \mathrm{KMI}$ who are in Grammar Class. Then, the researcher found the data from test and questionnaire. The data are analyzed by using some steps, they are: (1) scoring the students' answer, (2) Identifying the Students Errors in Passive Sentences, (3) classifying the errors, (4) coding the data, (5) finding the causes of errors.

\section{FINDINGS AND DISCUSSION}

In order to find data and information of the student's difficulties in four tenses of passive voice, there are: simple present, simple past, present continuous and past continuous tenses, the writer applied 20 questions that the students were asked to transform the active voice into passive voice

From 39 students who participated in objective sentence transformation test with 20 items of questions, $17.65 \%$ of the students have difficulties in answering item number 1 , $8.82 \%$ students find the difficulties in question number $2,79,41 \%$ students fail to correctly answer in item number 3 , $97.06 \%$ students have fail in question number $4, \quad 64.71 \%$ students have difficulties in number $5,23.53 \%$ students incapable to change active to passive form in number $6,94.12 \%$ students find the difficulties in item number $7,88.24 \%$ students might fail in answering question item number $8,41.18 \%$ in number 9 , and $85.29 \%$ in number 10 . In questions item number 11 to 20 , the students of Elmadani Islamic Boarding School also find the difficulties to change active into 
passive sentence. $38.24 \%$ in number 11 , $61.76 \%$ in number $12,61.76 \%$ in number $13,61.76 \%$ in number $14,73.53 \%$ in number $15,94.12 \%$ in number $16,50 \%$ in number $17,29.41 \%$ in number $18,100 \%$ in number 19 , and $44.12 \%$ in question item number 20.

The factor contributing to the student's difficulties would be detailed based on the data gathered from the questionnaires. Based on the sources of error that explained by Brown (1993), the researcher formulates the statements of the factors contributing to the student's difficulties that divided into four categories, they are Intra-lingual Transfer, Inter-lingual Transfer, Context of Learning, and Communicative Strategies

Based on the findings, the researcher found that there were several students who made errors after they had completed the test, they are, verbs changes, inappropriate use in to be, placement of subject, and placement of verb.

\section{Verbs changes problem}

There were $32.35 \%$ of the third grade students failed in changing the verbs. The students could not change the verb into appropriate forms in order to change active sentences to passive ones. There were two types of verbs that were difficult for the students themselves, that is: regular and irregular verb. It can be seen in questions items number $3,4,5,8,10,11,12,15,17,18, \quad$ and 20 . Example: Question number 8

Question 8: The international television's channels are broadcasting the Covid19. In this case, the students failed to change the verb "broadcast" to its past participle form (broadcasted). Instead, the students responded by answering "broadcasting. 


\section{Inappropriate use of to be}

Regarding this problem, there

were $23.38 \%$ students failed to place the suitable "to be" for the sentence in active sentence into passive sentence. It showed that the students were confused about choosing the right to be in their answer. It could be seen from several questions of the test (4, $6,7,11,13,17$, and 19).

\section{Example no 4}

Question 4: The children were buying the candies at the market. In this case, the students were incapable of identifying the correct to be for the singular noun. They mistook the singular to be for "the children" by singular noun. They mistook the singular to be for "the children" by writing "were" rather than "was". It could be concluded that they did not fully understand the use of to be.

\section{The placement of subject}

According to the result of the test, $13.82 \%$ students were unable to transform the position of object in active sentence into the place of subject in passive sentence. They might fail to provide appropriate answer for question number $3,4,6,7$, $8,9,10,11,12,14,17,18,19$.

Example question 4: The children were buying the cadies at the market. In this case, the students failed to identify the object in active sentence to become the subject in passive sentence. In this question above, some students shifted "at the market" the adverb of times of a sentence into the position of subject in passive sentence.

\section{The placement of verb}

Based on the table above, there were $6,91 \%$ students failed to identify the verb and the placement of 
verb. It can be seen in question items number 4, 5, 8, 10, 11, 17 and 19.

Example Question 8: The International television's channels are broadcasting the Covid19. In this case, some students incapable to identify the placement of verb, some of them answered "broadcasting the Covid 19 by the international television's channels". From the students' answer, it shows that the students failed to put the verb in appropriate place, they put the verb in the beginning of the sentence as the subject in passive voice.".

\section{Emission of verb}

The third students of ElMadani Islamic Boarding School might fail to identify the verb in active and passive form and some students also did not put the verb in passive sentence. It can be seen in number 5, 10,14 , and 15 .

Example Question 5: The performance grabs people's attention. In this case, some students failed to find the verb in active sentence. They answered "people's attention by the performance". That situation shows that the students did not put the verb in passive sentence.

\section{Emission of "by"}

5, 29\% students might fail to understanding the rule in passive voice. It can be seen in question number $1,6,7,8,9,10,13,15,18$ and 2. Example Question 15: Mark Zuckerberg invented the Facebook. In this case, student also the same mistake as the first example, whereas the students might be incapable to provide relevant answer because their answers indicate that they poor understanding and lacks of context 
understanding. In this question some

of them not put the word "by" before

the subject of passive voice sentence

in simple present tense form.

\section{Emission of "to be"}

As many students of Elmadani incapable to identify the use of "to be" and confused about the placement of to be, it is difficult for them because they did not fully understand the context of passive voice. It can be seen in question items number $1,4,5,6,8,10,11,13,14$, 15,17 , and 19 .

\section{Example Question 5: The} performance grabs people's attention. In this question, students failed to identify the placement of "to be", even they do not put the "to be" in passive sentence. Students answer "people's attention grabbed the performance". From the answer shows that the students did not fully understand the rule of passive voice, that is the reason why the students do not put the "to be" in the sentence of passive form. The finding of the questionnaires is explained as follows: Statement (1,2, and 3) indicated the context of learning. It was found about 10 students were found that they ever found book's reference that false on informing the rules of passive voice. Most of the students did not experience and most of them did not find misinformation about English especially in passive voice whether it was from the teacher or textbook. But, some students found that sometimes teacher explain the material especially in passive voice not clear enough, that makes them misunderstand about that. It was relevant with Brown's theory (1980) that stated that students often made errors because of misleading by the teacher or faulty presentation from textbook. There were 15 students felt that studying passive voice is easy and interesting because the teacher delivered the material very well but there were 24 
students who could not absorb the material because the teacher's explanation is difficult to understand. There were 31 students agreed that the class environment affected the students to studying in class. indicate the classroom atmosphere. It shows 39 students were affected by this factor in learning process. In fact, the class condition was still far from what was expected. The class was crowded and uncomfortable for the students. Uncomfortable here was shown by; the students from another class or their classmate disturb the teaching and learning process usually yelling and calling them, the condition in the class such as hot weather, noisy class which made the students spent most of their time for drying their sweat and could not focus on what teacher was explaining.

Statement (3 and 4) indicate teacher's communicative strategy. In this field, there were 23 students who could not understand active and passive voice that explained by the teacher. Then, there were 22 students who could not use the pattern of passive voice that explained by the teacher.

Statement $(5,6,7,8,9,10)$ indicate intra-lingual factor which was the result of the failure of learning by the students. It is relevant with Dulay (1982) who investigated that mostly the failure was caused by the limit experience that the students had in using English. Eventually, most of the students just learnt in English at school, indeed only in English class. They were having less practice outside. 20 students of El-Madani Islamic Boarding School difficulties to change verbs in active sentence to become past participle form in passive sentence especially in irregular verbs. 21 students did not know the formula in different tenses of passive voice, it will be difficult for them to answer the question in appropriate forms in order to change active sentences to passive ones. 9 students also have problem 
in pronoun because their answer indicated that they have poor understanding in pronoun. 17 students agreed the used of "to be" become one of the problems in passive voice and 18 students experienced difficulties to distinguish between singular and plural.

Statement (11 and 12) indicated the interlingual factor contributing to the students' difficulties which is influenced by the students' first language (Dulai: 1982). Because passive voice was different from Indonesian, students tend to adopt Indonesian structure when using English because it was the only system they could use before they are familiar with English structure. There were 27 students who interfered by their first language.

\section{CONCLUSION}

The researcher gives three points of conclusion of this study they are: 1).The kinds of errors commonly made by the students of El-Madani Islamic Modern Boarding School Deket Lamongan in changing active voice to passive voice are errors of omission, errors of addition, errors of miss-formation, and errors of miss-ordering. Omission of verb (OOV), Omission of by (OOB), Omission of to be (OOTB). Addition of verb (AOV), Addition of by (AOB), Addition of to be (AOTB). Miss-formation of verb (MFOV), Miss-Formation of by (MFOB), MissFormation of to be (MFOTB), Missformation of Subject (MFOS), MissFormation of Object (MFOO). Missordering of verb (MOOV), Miss-ordering of by (MOOB), Miss-ordering of to be (MOOTB). (2) The students of Elmadani Islamic Boarding School have difficulties in understanding passive voice especially in four tenses, there were; (a) simple present tense, (b) simple past tense, (c) present continuous tense and (d) past continuous tense. (3) The causes of errors in using passive sentence in writing made by the students of El-Madani Islamic Modern Boarding School Deket Lamongan are: intralingua transfer, interlingua transfer, context of learning, 
and communicative strategy. It shows that classroom atmosphere, lack of experience in using English, teacher's explanation was not clear enough, the differences between passive voice in Bahasa Indonesia and English. Student's poor understanding relies on their lacks of understanding on the verbs changes, the use of to be verb and placement of subject. The last one, their poor understanding also relies on lacks of context understanding and background knowledge.

\section{REFERENCES}

Brown B. (1993). Hematology: Principles and Procedudures, $6^{\text {th }}$ ed. America: Lea \& Febiger.

Brown, H. Douglas. (2004). Teaching by Principles an Interactive Approach to. Language Pedagogy. Longman.

Brown, D. H. (2000). Principles of language learning and teaching. $\left(4^{\text {th }}\right.$ ed.).

Corder, S. Pit. (1981). Error Analysis and Interlanguage. Oxford. Oxford University. Press.
Creswell, J. W. (2014). Research Design: Qualitative, Quantitative, \& Mixed Method Approaches. Thousand Oaks California 91320: sage, Publication, Ink.

Erdogan, V. (2005). Contribution of Error Analysis to Foreign Language Teaching. Journal of the Faculty of Education Mersin University.

Hubbard, P. (1983). Bridging the Gap between Chaos and Coherence in ESL.

James, Carl. (1998). Error in Language Learning and Use: Exploring Error Analysis. London. Longman.

Lado, R. (1996). Lingustics Across Culture. Ann Arbor: University of Michigan Press.

Murcia, M. C., \& Hilles, S. (1987). Techniques and Resources in Teaching Grammar. Newyork: Oxford University Press.

Sembiring, M. Zarlis, Dedy Hartama, Elvi Wani. (2011) International Conference on management and Artificial Intelligence

Slinker, L. (1992). Language Transfer in Language Learning. Philadelphia: John Benjamins

Sugiyono. (2013). Metode Penelitian Kuantitatif, Kualitatif dan $R \& D$. Bandung: Alfabeta.CV.

Yusuf, Munawir.dkk. (2003). Analisis Data Penelitian Kualitatif. Jakarta : Raja Granfindo. 